\title{
Transformation of the System of Bilingual Education in the Republic of Tatarstan: Crossover Ethnolinguistic Controversies
}

\author{
Olga Maximova ${ }^{1}$, Vladimir Belyaev ${ }^{2}$, Olga Laukart-Gorbacheva ${ }^{3}$
}

\begin{abstract}
The relevance of the problem range addressed in the study is conditioned by the system of education functioning under multiculturalism in modern polyethnic societies and their social stability much depending on the balanced use of languages of ethnoses that reside in the region as well as on the respectful attitude to their representatives in daily life. Thus, the system of education has to take into account the ethnic and religious, political, social and cultural requirements of the society offering highquality education to the consumers according to their expectations. The objective of the paper consists in revealing the topical problems of regional educational reforms aimed at implementing the principle of bilingualism in polyethnic and polyreligious region of Russia - the Republic of Tatarstan. The representative mass survey of population of the Republic of Tatarstan and a series of in-depth narrative interviews with representatives of various generations of Tatarstan citizens as the main methods used in the research. Based on the sociological survey conducted within the research project "Dynamics of real and conventional generations in information polyethnic and polyreligious society (a case study of the Republic of Tatarstan)", the following findings have been made. Scientific justification of the language policy being implemented in the republic and of the methodological support of bilingual educational programs are of poor level. A higher education system segregated according to the information carrier language prevails. There also remains a crossover controversy expressed in discontent in both Russianspeaking and to a significant extent Tatar-speaking urban population with the school educational policy of bilingualism. Results of the research cited in the paper can be used by the state authorities of the republic for elaborating the optimum bilingual language policy as well as in the practice of educational institutions implementing the bilingual education.
\end{abstract}

Keywords: bilingual education, teaching methods, policy of bilingualism, educational program, language identity, crossover ethnolinguistic controversy, upgrade of the Tatar language teaching methods.

\section{Introduction}

Post-modern societies develop in conditions of multiculturalism which brings about the necessity of a balanced ethnic and religious policy, and in particular, language policy. Some of the efficient mechanisms of language policy implementation in areas with ethnically diverse

\footnotetext{
${ }^{1}$ Assoc. Prof., Candidate of Sociology, Kazan (Volga region) Federal University, Kazan National Research Technical University named after A. N. Tupolev - KAI, olga_max@list.ru ${ }^{2}$ Prof., Doctor of Politics, Kazan National Research Technical University named after A. N. Tupolev - KAI, vlad_belyaev@list.ru ${ }^{3}$ Assoc. Prof., Candidate of Sociology, Kazan National Research Technical University named after A. N. Tupolev - KAI, olga241202@yandex.ru
} 
population is maintaining and developing the languages of the most numerous ethnoses residing in the region by teaching these languages at educational institutions. The optimum proportion of the ethnic groups' interests in educational programs allows using the languages of the ethnoses in a balanced manner while also maintaining their tolerant attitude to each other. Educational reforms aimed at implementing the bilingualism or multilingualism principle frequently have no scientific justification and are conducted under the influence of certain political or economical interests, which results in immediate public initiatives and escalation of tension in interethnic communication.

One of the important questions in the sphere of education is the implementation of bilingualism or multilingualism policy in areas with ethnically diverse composition of population (Byker \& Marquardt, 2016, Kopish, 2016). While working out the policy of functioning and development of educational institutions, the interests of ethnic groups have to be taken into consideration and an optimum proportion of two or more languages teaching has to be implemented in educational programs. Any biases towards any certain language are promptly responded to by the public.

Bilingualism in the Republic of Tatarstan is a historically formed result of a prolonged interaction of two main ethnoses, the Russian and the Tatar ones, for which close neighboring is perceived not as a problem but more as a cultural particularity of the republic. Meanwhile, bilingualism is not a direct reflection of bi-ethnic structure due to the presence of numerous Russian-speaking monolinguals and bilinguals first of all among the Tatar urban dwellers in Tatarstan. However, in various historical time spans, language policy did not always completely take into account the interests of both ethnoses, which was also reflected in educational programs of the republic's educational institutions.

It was only during the restructuring years of 1987-1991 that the actual discussions (both in scientific circles and in the mass media) on the questions of bilingualism commenced in Tatarstan openly. Previously, in the early Soviet time - in 1930s and 1950s, the compulsory learning of the Tatar language by Tatar origin schoolchildren and optional learning of Tatar by the Russian children were widespread at schools. With regard to this, it was the spoken Tatar language that Russian schoolchildren studied, in play and spectacular forms, using the words and idioms that were common for the daily speech mainly.

The first discussions about the role of the Tatar language, its evolution and obligation of all 
learners to study it regardless of their ethnic background were only to be heard during the "thaw" of the 1950-1960s within clandestine and semi-clandestine groups on the history of Tatar ethnos and its culture; the authors of the paper were told about the work of such groups by participants themselves during the in-depth interviews. V. Belyaev (2007) notes that Tatar ethno-national movement of that time had the goal of raising the status of the Tatar culture and language, expanding the authorities of the republic and possibly rendering the ethnicity political and was already institutionalized in the stagnation years, having created an elaborate network of ethnonational mobilization that consisted of a number of concentric circles. Its "external circle" represented the small isles of Tatar ethnic culture (at Tatar theaters, philharmonic society and other institutions of art, Tatar departments of pedagogical institute and university, at the institute of language, literature and history, in Tatar-speaking newspapers and magazines, later - at the conservatoire, the institute of culture, on the radio and television etc.). The communities were institutionalized by subtle semi-legal campaigning at the theatrical gatherings, shows, creative evenings, culture evenings, society parties and the like events where the ones concerned with the destiny of their people were selected from the "external circle" audience. The objectives of ethnicity volunteers' working in the external circle were to look for sympathizers ("clubmen") and to involve potential activists and adherents - constituents. The chosen ones got to the "medium circle" or "inner network" which was already busy with the consistent preparation of ethno-national politically charged most active members: by advocacy of the history of the Turkic peoples and languages, theology and history of Islam among the activists. The main function of the "medium circle" is forming the ethno-national elite and training the reserve staff for the official ruling elite. At the head of all this work there was the "core" (the caucus of ethnonational "counter-elite"). The caucus included both the forefront leaders (organizers, ideologists from among scientists and smooth operators from among cultural figures) and the second unit actors (leaders' backup men, "arguers", "referees" and constituents). The caucus had its representatives in the city and municipal authorities, in security and other ministries of the republic, and it also supervised the personnel policy at the middle level (in areas, ministries and government agencies). The main functions of the caucus of such "counter-elite" were management of the ethnic movement, development of its strategy, injection of power with ideas and people (permeating into the power) as well as exercising pressure on the power. The caucus of the "counter-elite" practically interspersed with the ruling elite of neo-nomenclature so it 
cannot be called opposition to the full extent. Thus, the ethnic movement was an integral system in which each "circle" was a subjected stage, a form for being selected into the next level (Belyaev, 2007, p. 306-308). The above processes actually brought about flourishing of ethnocentrism in the late Soviet and restructuring times.

In the late Soviet time, discussions on the problem of bilingualism were provoked by a number of functions of the Tatar language declining, its going away into "kitchens and countryside". Hence one of the reasons for uplift of the ethnocentric and republican (given the obvious poor compatibility of these two vectors) at the end of the 1980s was the aspiration to revive the social and state functions of the Tatar language. As a form of such renaissance, the Tatar ethno-political movement and leaders of the republic suggested to vest the Tatar language only with state functions in Tatarstan and to make studying it an obligation for all learners. At the same time, the multinational movement "Soglasie" ("Concord") emerged in the republic which put forward the idea of equal state recognition of two main languages and the idea of compulsory study of both languages at school, although in a different scope, with the Russian language prevailing essentially.

Further on, the public discussion turned quite harsh, which was expressed in the Law of the Republic of Tatarstan "On state languages of the Republic of Tatarstan and other languages in the Republic of Tatarstan" that first appeared in 1992 and was updated several times. The law prescribed that both languages be studied in equal scope as well as the subject-based (not objectbased) principle in relation to mastery of both languages be observed by the state authorities. This means it is not merely an "object", or a state agency, that had to give a reply in the same language it had been addressed to (for this, it suffices only one official in charge of answering the requests to know both languages) but each "subject", i.e. each official had to know both languages - which is physically impossible as of now and in practice leads to mono-ethnization of power structures. Discussions associated with this go on both in the scientific community (including thesis works, monographs and papers) and in the Internet, on websites of newspapers, and to a smaller extent - on the radio, television and in the official "paper" printed media.

The introduction of compulsory study of the Tatar language and literature at comprehensive schools and professional educational institutions of Tatarstan in the early 1990s caused an immediate people's response in the printed media of the republic (Khodzhaeva, 2011).

Broad public discussions on the problem of proportion of the Russian and Tatar languages 
being taught go on, and so do the social initiatives. Among the most noticeable social activities in this direction, the following can be named:

- created in 2008, the Web community "The Russian language at schools of Tatarstan" keeps functioning actively, currently listing over 11 thousand members;

- in June, 2010, 30 collective appeals against the republican "Strategy of development of education in the Republic of Tatarstan for the years 2010-2015" ("Kilechek") were signed and distributed, as according to the activists the said strategy involved consolidating the priority positions of the Tatar language in the system of education while implying no development in the study of Russian;

- in February, 2011, there was a one-person picket with the slogan "RT ME\&S, bring the Russian language back to schools!", and in the same month, an open letter was published and collection of signatures of schoolchildren's parents was started;

- on April 16, 2011, leaders and activists of the Society for the Russian culture rallied in Kazan for the defense of the Russian language and its position in the republic's system of education;

- on June 9, and September 7, 2011, pickets were organized in Kazan for the defense of Russian;

- in 2012, due to the greater quantity of official appeals to the federal authorities by the public organizations and parents of Tatarstan and Bashkortostan, Russia's State Duma Committee for Nationalities proceeding from the results of expert evaluation conducted by the Committee concluded that the regions' actions in setting equal the scopes of study of Russian and national languages ("the language serving all spheres of the society - Russian - certainly cannot be equated to a language of local functioning - Tatar, Bashkir etc.") were illegal. However, no essential change in proportion of the Russian and Tatar languages being taught took place in educational programs of Tatarstan educational institutions;

- in June, 2013, there was a rally in the center of Kazan, in November - a march under the slogan "For the Russian language";

- in December, 2013, a picket for the defense of Russian was organized in Moscow;

- in February, 2014, one-person pickets took place in Kazan;

- in May, 2015, an open letter to the President of the RF "Save the Russian language and interethnic concord in Russia's national republics" was published; 
- in April, 2017, the rally "Against the language tyranny in Tatarstan" was organized in Kazan;

- in May, 2017, Kazan saw the parents' protest activated against selection to a "polylingual" school - one with the Tatar language of teaching in most grades being created in a new district of Kazan (where the shortage of schools is quite acute) (Vasilyeva, 2017).

According to some researchers, the concept of the "native language" in Tatarstan is ideologically charged. Throughout the entire post-Soviet time, it was it that formed the basis for rhetorics of Tatar nationalist groups. Today, the concept is being actively borrowed by campaigners for the position of the Russian language. For them, the principal problem of public debates is Russian being taught at all Russian-speaking schools of Tatarstan "under the curriculum of national schools". Thus, formally, Russian has got the status of a non-native language - for ethnically Russian schoolchildren too, while Tatar is taught as a "native" for everyone. The Russian-speaking public believes this leads to impairment of the children's rights for getting the knowledge on their native language in full (here the scope of learning the Russian language in "non-national" regions of Russia is meant) (Khodzhaeva, 2011).

It should be pointed out that the demands of the public and, first of all, the Russianspeaking parenting community are focused not on completely canceling the learning of Tatar but on reducing the scope of study of Tatar for the schoolchildren (Russians, Tatars and others) whose mother tongue is Russian. As an argument, statements of parents are cited to the effect that they have to pay for extra services of private tutors of Russian for their children to score sufficiently in the uniform state exam (USE) when completing comprehensive schooling in order to be admitted to higher educational institutions. Moreover, results of studies show that most learners do not master Tatar at the due level because of low motivation and lacking methodological support, in particular - poor qualification of teachers of the Tatar language and literature, excessively complicated (one for higher educational institutions, in fact) theoretical study program.

The listed problems in transformation of the system of bilingual education in the Republic of Tatarstan demand being comprehended and studied at the empirical, theoretical and methodological levels.

\section{Literature Review}

The society has experienced dramatic change in all spheres of its existence during the 
recent decades. The rise of the new type of the society in the second half of the $20^{\text {th }}$ century is characterized by the researchers variously: as a post-industrial one (Bell, 1973); as an information one (Masuda, 1983, Castells \& Himanen, 2004); as an individualized (Bauman, 2001) or innovative one (Tarman \& Acun, 2010; Tarman, 2016); a society of risk (Luhmann, 1991; Beck, 1992); a society where the notions of "work" and "capital" are replaced by the "knowledge" and "information" ones (Toffler, 1980, Mansell, 1998); a learning society (Hutchins, 1968, Husen, 1974); the century of bifurcations (Laszlo, 1991) etc. The like social transformations render it necessary to change the educational paradigm too.

The analysis of the context of transformations has revealed a higher role of education and learning at the personal level which is characteristic for the new type of the society (Levy, 1966, Inkeles, 1976, Dahrendorf, 1979, Kumar, 1988, Naisbitt \& Aburdene, 1990, Giddens, 1990). The modern consumer of educational services is aimed to a larger extent at obtaining the practical, utilitarian knowledge, skills and competences and to a smaller extent - the universal theoretical knowledge (Maximova et al., 2016). Given the conditions of dual ethnic composition of the population in the certain region, and, in particular, approximately equally numbering shares of the population belonging to different language groups, there is also the problem of bilingualism actualized in the sphere of education.

As a result of globalization and development of world communication between different cultures and countries, various languages produce a potent effect on each other. E. Bialystok (2001) points out that monolingualism as a characteristics of speech of the modern adult is a fiction because any modern language contains words borrowed from other languages in its structure. In the formed world situation, owing to the stable increase of the quantity of people speaking several languages, bilingualism became a kind of phenomenon of the modern times. This range of problems has gained its popularity and is being researched widely by specialists of various scientific fields.

According to Common Underlying Proficiency Theory (Baker, 1996), two languages used by an individual function within the human conscience via one and the same central cognitive system, though being separated from each other: "When a person owns two or more languages, there is one integrated source of thought" (Baker, 1996, p. 147).

Bilingual education implies organizing the educational process in several languages at the same time and is used in various educational institutions of countries where, for instance, there 
are two official languages or an ethnic minority language actively comes into its own alongside with the official one.

Thus, under the dual ethnic composition of the population, there emerges a new social request for the system of education in solving the tasks of upbringing, education, and if necessary, rendering correction assistance to the rising generation with the linguistic particularities of the modern integrated society borne in mind. In order to solve the set task successfully, the relevant necessity arises to form techniques of teaching two languages to representatives of both ethnic groups. However, here the problem emerges which is expressed in having to ensure for parents of minor children the right to choose from educational programs and techniques oriented to bilingual education.

The standpoints of the international community in education and, in particular, in preservation and development of languages, the problems of teaching these are reflected in UNESCO documents elaborated in the recent decades: UNESCO Universal declaration on cultural diversity (2001); Convention for the safeguarding of the intangible cultural heritage (2003); Recommendation concerning the promotion and use of multilingualism and universal access to cyberspace (2003); Convention on the protection and promotion of the diversity of cultural expressions (2005). UNSECO recommends the member countries when developing their national language policies to support the diversity of languages by using and disseminating them, to promote teaching of several languages at different levels of education commencing with early childhood, to use methods of communication that run traditional in the culture and to keep the specific character of pedagogical systems, as well as to disseminate linguistic diversity by using the developments of the state-of-the-art information technologies and opportunities of the world information networks (Smeets, 2005).

One of UNESCO projects aimed at integrating national languages in the educational systems suggested a staged schedule of measures on reforming the educational systems in line with introduction of language training subjects. While emphasizing the complexity and social responsibility of introducing the national languages into the educational process, as well as having to take into account the national particularities and capacities, UNESCO experts recommended a number of main stages of the reform of education for implementing the national languages into educational programs (Dwyer et al., 2008). They are as follows:

- creating the scientific basis for educational programs upgrade relying on scientific 
Maximova et al.

research of linguistic and sociolinguistic particularities of the region;

- making the problems of language policy implementation in the educational sphere relevant and engaging the official figures concerned as well as the public in order to render the expected educational reforms legitimate and popular;

- training the personnel who are capable of implementing the expected changes in educational programs and ensuring quality teaching of the language subjects introduced at a high professional level;

- forming the methodological support of the educational reforms being conducted (planning, development, production, distribution and control of the required courseware and training measures that would resolve any difficulties and problems of language subjects introduction arising);

- ensuring the standard base and legal framework for the transformations conducted at the regional educational institutions;

- preparing the financial and technical base so as to ensure the efficiency and longevity of the educational reforms brought into life.

Bilingual education at the contemporary stage of its development is the subject of an extensive discussion among politicians, teachers, linguists, sociologists, philologists and parents. Likewise, the very notion of bilingualism is quite debatable. With regard to this, it makes sense to outline the brief chronology of the term being used in scientific discourse.

L. Bloomfield (1933) was one of the first to characterize the notion of bilingualism; he insisted that a bilingual is a person who speaks both languages fluently.

U. Weinreich (1953) determines bilingualism as the practice of alternate use of two languages. The Russian researcher V. Yu. Rosenzweig (1972) pointed out that by bilingualism mastery of two languages and regular switching between them depending on the communication situation is usually meant.

The Russian scholar A. D. Schweizer (2012) singles out the first language as one's mother tongue and the second language as the unrelated but being in a wide use with a certain ethnic community. The author specifies that a person can have different levels of mastery in the two languages: being fluent in spoken colloquial language or in written literary one or in both forms. According to Schweizer, one of the important sociolinguistic problems is that of social aspects of bilingualism. In conditions of bilingualism, two languages coexist within one community who 
use the languages in various communicative spheres depending on the social situation and other parameters of communicative act.

F. Grosjean (1989) determined a bilingual as a person who can "function" in both languages depending on the necessity. Meanwhile, he criticizes the monolingual or fractional view holding that the bilingual is (or should be) two monolinguals in one person. Grosjean stands up for the bilingual or holistic view stating that it is a unique and specific speaker-hearer that coexistence of two languages in the bilingual person produces.

S. Dopke (1992) distinguishes between the productive and receptive bilingualism. By productive bilingualism, a person's quite profound mastery of two languages as an educational competence is meant. In case of receptive bilingualism, people can understand the speech addressed to them and probably even read in the second language but they cannot actively use this language.

S. Romaine (1995) described six models of "home bilingualism" from the standpoint of social and linguistic particularities, with a greater or smaller status of each of the languages and the language material received by children taken into account. The same context is explored by the Russian authors A. A. Zalevskaya and I. L. Medvedeva (2002) who single out the following types of bilingualism. The natural (everyday) bilingualism means that the second language is mastered owing to the speech practice without getting deep into studying the language particularities of the language being learned. The artificial (academic) bilingualism involves certain pedagogical efforts and techniques in mastering the second language.

The fundamental foundations of sociolinguistics were laid down in the 1920-1930s by the Soviet scholars V. V. Vinogradov (1923), L. P. Yakubinskiy (1923), R. O. Schor (1926), E. D. Polivanov (1927), V. M. Zhirmunskiy (1936), and M. V. Serghievskiy (1936). The researchers proceeded from the Marxist approach viewing the language as a social phenomenon within the context of historic and materialistic principles of analysis of social relationships.

In the 1960-1970s, the interest in sociological problems of language was revived, which is first of all associated with the change in social needs and with the necessity of activating the pragmatic direction of sociolinguistic studies and applying their results in social practice, in particular, for developing the language policy up to the demands of the time and implementing it in educational programs, social and cultural projects (Galkina-Fedoruk, 1954, Avrorin, 1975, Nikolskiy, 1976, Stepanov, 1976, Desheriev, 1977). 
In the recent years, the problem of bilingualism in education has been quite extensively discussed both at the public level and in scientific discourse. Among the most significant works, the papers by S. Akhmetova (2013), G. Guzelbaeva (2013), L. Nizamova (2016) etc. can be singled out. These authors point at controversial trends in bilingualism functioning in the republic, persistent asymmetry in the use of the state languages towards the Russian language. Most Tatars of the republic being bilinguals and having mastered both Tatar and Russian to a sufficient extent while the Russian population as a rule failing to master the Tatar language in spite of the educational policy is considered by the said authors to be one of the principal problems. Nevertheless, it is only a limited quantity of authors who discuss another viewpoint voiced by the Russian population mainly and associated with the problem of the Tatar language being taught at the expense of reducing the academic hours for Russian (Khodzhaeva, 2011).

On balance, the analysis of literature reflects the multidimensionality of definitions and the evident lack of studies on the problem of bilingualism in Russia's system of education from the viewpoint of the social pedagogics, and certainly a later beginning of research in this area as compared to foreign scholars. At the modern stage of development of bilingualism in the Republic of Tatarstan being one of the polyethnic regions of Russia, the problem of development of techniques and methods of education and upbringing of children in conditions of bilingualism is actualized, as well as that of rendering them pedagogical and psychological assistance both in conditions of schooling and in intrafamilial socialization, as well as resolving social controversies in this sphere at the level of interethnic communication and performance of educational activity.

\section{Research Methods}

Within the research project "Dynamics of real and conventional generations in information polyethnic and polyreligious society (a case study of the Republic of Tatarstan)" supported by the Russian Foundation for Basic Research (the reported study was funded by RFBR under research project No. 17-06-00474 A), an integrated sociological study was performed by the research team with direct participation of the authors of this paper in AprilMay of 2017. The study included the following stages:

- representative survey of population of the Republic of Tatarstan ( $\mathrm{N}=1500$ people). The obtained data have been processed and analyzed using the SPSS software for statistical data processing; 
- a series of in-depth narrative interviews with representatives of various generations of Tatar citizens (the total of 20 interviews among the representatives of the Russian and Tatar ethnoses have been conducted), narrative analysis processing of the interviews.

One of the objectives of the integrated research consisted in identifying the key factors conditioning the specific character of transformation of the bilingual education system in Tatarstan and in finding out the attitude to this problem in two most numerous ethnoses residing in the region, the Russians and the Tatars.

The tasks of the research consisted in the following:

- revealing the particularities of the Tatar citizens' language identity;

- characterizing the attitude of various age cohorts of the population of Tatarstan towards educational programs implemented with the principles of bilingualism at the republic's educational institutions;

- describing the extent of acceptance/rejection of individual ways of mastering the two languages among the learners and their parents;

- identifying the problems of teaching the Russian and Tatar languages at educational institutions;

- finding out the opportunities for overcoming the crossover controversy in implementation of bilingualism at educational institutions of the Republic of Tatarstan.

The population of the Republic of Tatarstan became the object of the research.

The subject of the research was the population's attitude towards the problem of bilingualism being introduced and functioning within the republic's educational sphere.

The toolkit of the research consisted of a mass survey questionnaire and a guide for the in-depth interview which included the following thematic units:

- language identity of the republic's population, including one taken across generations;

- evaluation of the educational reforms conducted in the republic within the context of bilingualism;

- optimum variants of combination of educational needs for the two most numerous ethnoses, the Russians and the Tatars.

\section{Results and Discussion}

Comprehensive schools and professional educational institutions of Tatarstan comply with the federal laws and work in line with basis curricula setting the standards of hours for 
study subjects taught at the educational institutions. However, according to the Constitution of the Russian Federation (Art. 68), the Republic of Tatarstan being a subject of the Russian Federation has the right to set another state language and, consequently, introduce teaching of this language at its educational institutions.

The Law "On state languages of the Republic of Tatarstan and other languages in the Republic of Tatarstan" of 1992 specifies that "At state and municipal educational organizations, teaching and learning of Tatar and Russian as the state languages of the Republic of Tatarstan, of literature in Tatar and Russian within the educational programs accredited by the state are performed in accordance with the federal state educational standards. At comprehensive educational organizations and organizations of professional education, the Tatar language and the Russian language are studied in the equal scopes of the appropriate levels of general and secondary vocational education" (Law of the Republic of Tatarstan "On state languages of the Republic of Tatarstan and other languages in the Republic of Tatarstan", 1992).

The policy of bilingualism being implemented at comprehensive schools and professional educational institutions of the Republic of Tatarstan has got debatable consequences and is evaluated by the public, parents and learners in an ambivalent manner.

The research team with direct participation of the authors of this paper has conducted a representative survey of population of the Republic of Tatarstan, the sampling total amounting to 1500 people.

According to the results of the mass survey, language identity of the population of Tatarstan looks as follows:

- Russian is named as the mother tongue by over half of the republic's citizens (52\%); - around half of the respondents $(46,4 \%)$ consider the Tatar language to be their native;

- a significant part of non-Russian population of the republic $(68,5 \%)$ have pointed out that they speak Russian alongside with their mother tongue;

- only a minor share of the respondents $(14,4 \%)$ specified the knowledge of Tatar as a second language;

- in particular, the highest extent of knowledge of Tatar is marked with the youngest age group aged 16 to $24(42,7 \%)$, the lowest - with the oldest one whose age ranges from 65 years and older $(3,5 \%)$, which can be explained as a consequence of studying of the Tatar language having been introduced in the 1990s as mandatory throughout all educational institutions of the 
republic.

Concerning the problem of transformation of the bilingual education system, the following generational dynamics has been registered. The youth are more tolerant towards studying the Tatar language. So, the answer options of Tatar being mandatory for studying by everyone in the same or smaller scope as Russian were selected by $50,4 \%$ of the respondents aged 16-24 and by $49,8 \%$ of the 25-34-year-old ones. Meanwhile, with older generations, the figure ranges within $33,5 \%$ in 55-64-year-old ones and 40,8\% in those aged 45-54. Alongside with that, these data also show there is no shared opinion on this problem in the Tatar society. The representatives of Tatar ethnicity are much greater oriented to recognizing the studying of Tatar as mandatory as compared to the Russians and other nationalities.

However, the extent of knowledge of Tatar among the young respondents, according to their self-assessment, is clearly not up to the scope of hours allocated for studying of the language at educational institutions. With regard to this, only a small proportion (9\%) of the Russian youth specified their being fluent in Tatar. Each third one answered they had difficulty speaking Tatar, with each fifth one marking the passive understanding of the Tatar speech.

During the mass survey, the respondents' attitude towards the problem of proportion of teaching the Russian and Tatar languages at the republic's educational institutions has also been found out. So, it is only one fifth of the respondents who believe that Tatar must be studied at the equal scope with Russian; others are for reducing the quantity of hours allocated for the study of Tatar (see Table 1).

Table 1

Distribution of the respondents' answers to the question "What is your attitude towards the problem of teaching of the Tatar language at educational institutions of Tatarstan?"

\begin{tabular}{lc}
\hline \multicolumn{1}{c}{ Answer options } & $\begin{array}{c}\text { What is your attitude to the problem of teaching the } \\
\text { Tatar language? }\end{array}$ \\
\cline { 2 - 2 } & \% of those who have answered \\
\hline $\begin{array}{l}\text { 1. The Tatar language must be mandatory for } \\
\text { all learners in the equal scope with the Russian } \\
\text { language. }\end{array}$ & $20,4 \%$ \\
\hline $\begin{array}{l}\text { 2. The Tatar language must be mandatory for } \\
\text { all learners but in a smaller scope than the } \\
\text { Russian language. }\end{array}$ & $22,5 \%$ \\
\hline $\begin{array}{l}\text { 3. The Tatar language must be mandatory for } \\
\text { Tatars and optional for other nationalities up to } \\
\text { their wish. }\end{array}$ & $25,9 \%$ \\
\hline
\end{tabular}




\begin{tabular}{lc}
\hline $\begin{array}{l}\text { 4. The Tatar language must be only studied } \\
\text { optionally, regardless of a learner's nationality. }\end{array}$ & $27,1 \%$ \\
\hline 5. Other & $0,7 \%$ \\
\hline 6. At a loss to answer & $3,4 \%$ \\
\hline Total & $100,0 \%$ \\
\hline
\end{tabular}

As it is clear from the above data, the opinions of the respondents were not united yet quite a significant part of the surveyed ones $(27,1 \%)$ believe that Tatar must be studied optionally, up to one's wish, regardless of the learner's ethnicity - or as a compulsory subject by Tatars only, being an elective for others $(25,9 \%) ; 20,4 \%$ think Tatar to be mandatory for studying in the same scope as Russian, while 22,5\% - in a smaller scope. Meanwhile, it is the representatives of Tatar ethnicity who are much greater oriented to recognizing the studying of Tatar as mandatory as compared to the Russians and others.

Similar data were also obtained in the study by E. Khodzhaeva (2011) who points out that "so little as less than half of the Tatars (44\%) and 14\% of Russians support the current republican language policy in the sphere of education. The present-day demands of the Russian public - to make Tatar mandatory for studying by all schoolchildren but in a smaller scope - are supported by a quarter of Tatars and a little over a quarter (28\%) of Russians. As for the Russians, the majority of them (42\%) speak for voluntary learning of the neighboring people's language" (Table 2) (Khodzhaeva, 2011).

Table 2

Distribution of the respondents' answers to the question "Does the Tatar language need to be taught at schools of Tatarstan? If yes, in what forms?"

Does the Tatar language need to be taught at schools of Tatarstan? If yes, in what forms?

Tatars (in \%) $\quad$ Russians (in \%)

It must be a mandatory subject for all.

44

14

It must be a mandatory subject but with a smaller quantity of hours

25

28 allocated for it.

It must be as an option only, for the willing ones.

16

42

It must be mandatory for Tatars only.

11

10 
Schools of Tatarstan must be free from it at all.

I am at a loss to answer.
1

4
1

5

So, it can be seen that the results of representative mass surveys of population of the Republic of Tatarstan confirm the fact that it is not only the radically-minded public who call for reduction of the quantity of hours allocated for studying the Tatar language but also a significant share of the population.

This standpoint was also voiced by the informants of in-depth interviews conducted within the project.

So, Informant 1 , a secondary school teacher of the Russian language and literature was of the following opinion:

"Well, my attitude, it will be due to my profession, yes. I see children directly, I see them study, well, I remember schooling myself, when there was Tatar, even with two official languages, however, there already was much more Tatar than Russian. This is certainly unacceptable. I think there can be a greater quantity of Tatar for the children coming directly from Tatar families and exclusively up to their wish, here they study for advancing their language. But anyways, the majority of population here speak... yes, they speak a lot both Tatar and Russian. That is, almost all Tatars know Russian, and unfortunately not all Russians speak Tatar. So making such a thrust on the Tatar language at schools - as well as absolute deviation to the other side away from the Russian language - I think it is unacceptable. I believe it is yet the Russian language that has to form the cornerstone" (Informant 1, a woman, a Russian).

The informants also support the opinion that studying of the Tatar language has to be optional, up to one's wish:

"The informant: Yet the people who live in Kazan, in Tatarstan, they all can, yes, leave and they get enrolled, most likely, as far as I know the graduates of Kazan schools, they leave for Moscow and they leave for Saint-Petersburg. Russian is needed hundred percent there, and it is all there that the USE and the like, the like... while Tatar...

The interviewer: What should be the proportion of languages at school, here, in your opinion, and at all, do we need Tatar at school, as such, must it be there, in what form if it is needed?

The informant: Well, I would keep it as an option for the willing ones. 
Maximova et al.

The interviewer: An option?

The informant: I would leave it so, because yet the exam is, yes, the state Russian language. Be it not at the expense of Russian, well, but it is at the expense of Russian that they squeeze out the hours, and that is frustrating for me." (Informant 2, a woman, a Russian).

As an individual problem, the informants named the insufficient methodological level of teaching of the Tatar language at schools:

"Also, again, as a teacher and, basically, as a person who is - well, six years that is not much - not too long away from school. We can say, look, they study Tatar at schools since the first grade, and they study English - some of them since the second, others since the first, yet others since grade five, and they have Tatar five times a week while there is two or three times of English a week. Well, that is if we take a comprehensive school. But as they leave school, what we get is somehow completely different proportions. That is, for some reason, even with two or three classes a week children speak English much better rather than Tatar on which so much time is spent. And in fact, if we take the school program level-I couldn't string two words together. Well, this certainly can be in the red for me, but anyway... And again, wasting 5-6 lessons a week - this is, well, really, this is a pointless waste of time. Because anyways, again, when you work at school, you interact with children directly, and with the children, regrettably, Tatar may evoke no positive emotions whatever. That is, so much time is spent for the language, and even for the very children - well, it still is just some strange subject which they do not see what for they go to. Come, this is really so, and what is more, even with the Tatar children at times. And here we get the question, accordingly, what for, probably it really should be if it is better for one's soul and not just to tick the box. And well, we all know it fairly well, that going to school itself is for those children just to tick the box until say grade 9, and all the more so with the Tatar language classes. They just do not see what this is for." (Informant 3, a man, a Russian).

Meanwhile, it was emphasized that it is on the teacher's standpoint that the motivation in learning of Tatar depends, just like in the case of other languages:

"In fact, it depends on the teacher, but it also depends on the system of education first and foremost. For example, we had teaching practice, we taught Tatar and English, we tried to take a slightly different approach, so that it would be interesting for the learners themselves - not just reading and retelling stories. We tried giving the topics of lessons in another format. Look, 
English is taught and everyone likes the way English is taught while Tatar is taught and no-one wants to study it. Even me, I do not want to teach up to this program. And so absorbing the technique of teaching English we tried to teach Tatar, and it turned out to be very efficient. We had various listening comprehension tasks, discussions and surveys. Now it has already become popular, the Singapore technique and others. That is, certainly, a very strong motivation, not only for Tatar children but for the Russian ones too. I liked it so much when the Russian kids came to us asking "Are you coming back to us next year? We like the Tatar language so much!" (Informant 4, a woman, a Tatar).

Thus, the results of studies allow identifying some trends in the development of bilingualism in the sphere of education of the Republic of Tatarstan from the standpoint of their potential influence on interethnic communication, namely:

- ongoing active public discussions on the problem of proportion of the Russian and Tatar languages being taught, social initiatives of those supporting the language policy being implemented and of those advocating the reduction of the Tatar language component in educational programs confirm the fact that the problem keeps being relevant;

- language identity particularities of the Republic of Tatarstan population revealed in the course of research render it necessary that the bilingual component is preserved in educational programs but require a more scrupulous approach, finding out all opinions of the population, with these to be taken into account when implementing the educational policy;

- the majority of the questioned ones negatively evaluating language training practices at the republic's educational institutions demonstrates the poor level of scientific justification for the language policy being implemented and imperfection of methodological support for implementation of bilingualism in educational programs.

\section{Conclusion}

Under the modern conditions, the initial boost in transformation of the system of bilingual school (and even higher education institution) education in the Republic of Tatarstan has rolled back to a segregated education system, segregation based on the language information carrier. In particular, approximately the same (be it expanded in the menu) sectors of education have remained Tatar-speaking (Tatar journalism, history of Tatarstan, philology - literature including, as well as many study courses of agrarian direction) due to Tatar-speaking citizens and Tatar 
schools prevailing in the countryside. Meanwhile, the attempts of translating the training in the sphere of technical and natural sciences higher education into Tatar have failed to be perceived by the Tatars themselves.

School education policy represents a crossover controversy to the above fact. It still has the principle of equal study hours conserved for both languages, which does not work for the urban population first of all (both Russian and to a significant extent Tatar one).

The authors believe that the problem of proportion of hours allocated for studying of the Russian and the Tatar languages at the republic's comprehensive schools needs adjustment and bringing into greater accordance with the federal legislation. With the opinion shared by already not only individual social activists, but also by a significant part of the Russian and a considerable amount of the Tatar population, it is expedient to review the curricula in order to bring the quantity of hours allocated for Russian to the general Russian standard while also reducing the quantity of mandatory hours for learning of the Tatar language and introducing additional optional hours for all the willing ones.

The techniques of teaching the Tatar language at secondary school need a thorough upgrade with new interactive encouraging methods of teaching to be introduced. The authors think that the principle of Tatar teaching at schools has to be changed on top of that as well: the extensive learning of grammar has to be rejected in favor of teaching the communicative, spoken language skills that are more demanded in daily communication practices among the population of the republic.

The authors believe that under the modern conditions the Republic of Tatarstan has got all capacities for elaborating and implementing the optimum language policy and in particular educational programs which would take into account the needs and interests of representatives of the republic's principal ethnoses. Studying the conceptual approaches to the problem of bilingualism and multiculturalism, the positive world experience, the results of the republican educational practices, the Tatarstan citizens' language identity and their educational needs, as well as the capacities of the republic's educational institutions will allow developing the projects of educational programs designed to maintain the uniqueness of the ethnic cultures and the mutually tolerant attitude of their representatives in the today's conditions of multiculturalism.

\section{Acknowledgements}

The reported study was funded by RFBR under research project No. 17-06-00474 and by 
the RFBR and Government of the Republic of Tatarstan under research project No. 17-46-160490.

The authors express their profound gratitude to all informants of the research who demonstrated an interest in the study and gave the most detailed and frank answers to questions put to them. When collecting the empirical information, the ethics of human subject research was observed that consists in exclusively free-will participation in the questionnaire survey and interviews and in observing the principle of anonymity during processing and interpretation of the results.

The authors would like to thank the administration of Kazan National Research Technical University named after A. N. Tupolev - KAI (KNRTU-KAI) and Kazan (Volga region) Federal University at which the authors collaborate. 
Maximova et al.

\section{References}

Akhmetova, S.A. (2013). Tatar and Russian bilingualism in the regional context. Transactions of Kazan University. Humanities Series, 6(155), 7-14.

Avrorin, V.A. (1975). Problems of studying the functional side of language: on the question of the subject of sociolinguistics. L.: Science, Leningrad department.

Baker, C. (1996). Foundations of Bilingual Education and Bilingualism. Clevedon: Multilingual Matters.

Bauman, Z. (2001). The Individualized Society. Cambridge: Polity.

Beck, U. (1992). Risk Society: Towards a New Modernity. London: Sage.

Bell, D. (1973). The Coming of Post-Industrial Society: a Venture of Social Forecasting. N.Y.: Basic Books.

Belyaev, V.A. (2007). Intelligentsia as a subject of the Russian political process: the federal and regional aspects. Thesis paper of the doctor of politics. Kazan.

Bialystok, E. (2001). Bilingualism in Development. Language, Literacy and Cognition.

Cambridge: Cambridge University Press.

Bloomfield, L. (1933). Language. New York: Henry Holt.

Byker, E.J. \& Marquardt, Sh. (2016). Curricular Connections: Using Critical Cosmopolitanism to Globally Situate Multicultural Education in Teacher Preparation Courses. Journal of Social Studies Education Research, 7(2), 30-50.

Castells, M. \& Himanen, P. (2004) The Information Society and the Welfare State: The Finnish Model. Oxford: Oxford University Press.

Dahrendorf, R. (1979). Life Chances. Chicago: University of Chicago Press, 162-172.

Desheriev, Yu.D. (1977). Social linguistics. On the general theory foundations. Moscow: Science.

Dopke, S. (1992). One Parent One Language: An Interactional Approach. Amsterdam: John Benjamins.

Dwyer, A., Brenzinger, M. \& Yamamoto, A.Y. (2008). UNESCO Program "Safeguarding of Endangered Languages". Online Publication. URL: http://www.ddl.ishlyon.cnrs.fr/Colloques/3L_2008/3LCourseMaterial/YamamotoDwyer_AAA_UNESCO.pdf

Galkina-Fedoruk, E.M. (1954). Language as a social phenomenon. M.: State Educational and Pedagogical Publishing House of the Ministry of Education of RSFSR. 
Giddens, A. (1990). The Consequences of Modernity. Cambridge: Polity Press.

Grosjean, F. (1989). Neurolinguists, Beware! The Bilingual is Not Two Monolinguals in One Person. Brain and Language, 36(1), 3-15.

Guzelbaeva, G. (2013). Practices of use of the state languages by citizens of Tatarstan in the situation of official bilingualism. Philology and culture, 4, 44-51.

Husen, T. (1974). The Learning Society. L.: Methuen.

Hutchins, R.M. (1968). The Learning Society. Santa Barbara (CA): Praeger. P.41-61.

Inkeles, A. (1976). A Model of the Modern Man: Theoretical and Methodological Issues. In: Black C.E. (ed.) Comparative Modernization. New York: Free Press, 320-348.

Khodzhaeva, E.A. (2011). The Tatar language at schools of Tatarstan: public debates and the population's opinion. Emergency Reserve, 6, 245-254.

Kumar, K. (1988). The Rise of Modern Society: Aspect of the Social and Political Development of the West. Oxford: Basil Blackwell.

Kopish, M.A. (2016). Preparing Globally Competent Teacher Candidates Through CrossCultural Experiential Learning. Journal of Social Studies Education Research, 7(2), 75108.

Laszlo, E. (1991). The Age of Bifurcation: Understanding the Changing World. Philadelphia: Gordon \& Breach.

Law of the Republic of Tatarstan "On state languages of the Republic of Tatarstan and other languages in the Republic of Tatarstan" (version of the RT Law dated 28.07.2004. No. 44ZRT). (1992). URL: http://base.garant.ru/8102506/

Levy, M. (1966). Modernization and the Structure of Societies. Princeton: Princeton University Press.

Luhmann, N. (1991). Soziologie des Risikos. Berlin / New York (de Gruyter).

Mansell, R. (1998). Knowledge Societies: Information Technology for Sustainable Development. Oxford: Oxford University Press.

Masuda, Y. (1983). The Information Society as Postindustrial Society. Washington.

Maximova, O., Belyaev, V., Laukart-Gorbacheva, O., Nagmatullina, L. \& Hamzina, G. (2016). Russian Education In The Context Of The Third Generation Universities`Discourse: Employers' Evaluation. International Journal of Environmental and Science Education, 11(16), 2016, 9101-9112. 
Naisbitt, J. \& Aburdene, P. (1990). Megatrends 2000: The New Directions for the 1990's. New York: William Morrow.

Nikolskiy, L.B. (1976). Synchronous sociolinguistics (Theory and problems). Moscow: Science.

Nizamova, L.R. (2016). Ethnic Tatars in Contention for Recognition and Autonomy:

Bilingualism and Pluri-Cultural Education Policies in Tatarstan. Nationalities Papers, 44(1), 71-91.

Polivanov, E.D. (1927). The revolution and literary languages of the SSR Union. The revolutionary East, 1, 36-57.

Romaine, S. (1995). Bilingualism. Oxford: Blackwell.

Rosenzweig, V.Yu. (1972). Language contacts. Leningrad: Science.

Schor, R.O. (1926). Language and society: a sketch. Moscow: Rabotnik prosveshcheniya.

Schweizer, A.D. (2012). Modern sociolinguistics. Theory, problems, methods. Moscow.

Serghievskiy, M.V. (1938). History of the French language. Moscow: Uchpedghiz.

Smeets, R. (2005). UNESCO Activities for Safeguarding Endangered languages. Online Publication. URL: http://lingsib.iea.ras.ru/en/articles/smeets.shtml

Stepanov, G.V. (1976). Typology of language conditions in countries of the Roman speech. Moscow: Science.

Tarman, B. (2016). Innovation and education. Research in Social Sciences and Technology, (1)1, 77-97.

Tarman, B. \& Acun, I. (2010). Social Studies Education and a New Social Studies Movement. Journal of Social Studies Education Research, 1(1), 1-16.

Toffler, A. (1980). The Third Wave. Bantam Books.

Vasilyeva, N. (2017). School for children with Tatar surnames to open in Azino. Evening Kazan, May, 27, 62-63, 1-2.

Vinogradov, V.V. (1923). On tasks of stylistics. Observations on the style of protopope Avvakum's hagiography. In: Russian speech. Coll. of papers, ed. by L.V. Shcherba. Vol. I. Pgr., 195-293.

Weinreich, U. (1953). Languages in Contact: Findings and Problems. New York. Yakubinskiy, L.P. (1923). On dialogical speech. In: Russian speech. Coll. of papers, ed. by L.V. Shcherba. Vol. I. Pgr., 144-160. 
Zalevskaya, A.A. \& Medvedeva, I.L. (2002). Psycholinguistic problems of educational bilingualism. Tver: Tver State University.

Zhirmunskiy, V.M. (1936). National language and its social dialects. Leningrad: Khudozhestvennaya literatura. 